УДК 39(497.722)(049.3)

https://doi.org/10.55302/MF2077-78341n

Боре Неделковски

\title{
СЕЛСКОСТОПАНСКИ ОБЈЕКТИ ВО ЕТНИЧКИОТ ПРЕДЕЛ КРИВОПАЛАНЕЧКО
}

\begin{abstract}
Апстракт: Предмет на елаборација во овој труд се селскостопанските објекти, кои ги користат луѓето за вршење на одредена стопанска активност, во етничкиот предел Кривопаланечко. Во трудот се претставени следните селскостопански објекти: амбар за чување жито и брашно, плевна (племьа) за чување сено и слама, штала за чување добиток, кош за чување пченка, трло за чување овци, кочина за свињи, кокошарник за кокошки, казаница за варење ракија, фурна за печење леб, сушара за месо, пчеларник, бунар, воденица за мелење жито, валавица (кош) за валање јамболии. Во трудот се опишани конструктивните елементи од кои се изградени селскостопанските објекти и функционалноста на објектите.
\end{abstract}

Клучни зборови: Етнички предел Кривопаланечко, селскостопански објекти.

\section{Увод}

Етничкиот предел Кривопаланечко се простира на крајниот североисточен дел на Република Македонија, на надморска висина од 400 м (Славиште) до 2252 м (врвот Руен на Осоговските Планини). Етничкиот предел Кривопаланечко има 34 населени места, градот Крива Паланка, кој е општински центар и 33 селски населби. Општина Крива Паланка на запад се граничи со општина Ранковце, на север - со општините Трговиште и Босилеград (Р Србија), на исток - со општината Кустендил (Р Бугарија) и на југ се граничи со општините Македонска Каменица, Кочани и Кратово. Етничкиот предел Кривопаланечко му припаѓа на Шопската етничка област (Етнолошки атлас, 1983, 125), која се простира во: Р Македонија, Р Бугарија и Р Србија. Македонскиот Шоплук се простира во средниот тек на р. Пчиња со 10-те пчински села: Козјачија, Поткозјачија, Средорек, Кривопаланечко, Осоговија, Пијанец и Малешево. Радовишки Шоплук е енклава на Македонскиот Шоплук. Заради иселувањето на Шопите од својата матична територија и нивното населување во соседните котлини и градови, шопската културна граница се поместува на југ, во Овче Поле, како најпривлечен предел за доселување на Шопите, Кратовско и Кочанско (Светиева, 2005, 12 13).

Населението во Шопската етничка област се нарекува Шопи, кои се лимитрофна етничка група со посебни дијалектни карактеристики и со карактеристични елементи во: материјалната, нематеријалната и социјална култура. Во поглед на: потеклото, реалното и симболичкото значење на етнонимот/егзонимот Шоп постојат бројни тези, застапувани од етнолози и антрополози од Балканот и од Европа. Систематизирани научни согледувања во врска со етнонимот/егзонимот Шоп дава и проф. д-р Анета Светиева. Таа истакнува дека етничкото име Шоп се јавува како етноним, етникон, топоним, 
патроним, како ознака за општествен статус, како име со симболичко значење поврзано со стопанска дејност, место на живеење. Почнувајќи од крајот на 19 век, па до денес, името Шоп вклучува одреден пејоративен аспект со значење на „прости луѓе“: селани, овчари, планинци, рудари, зидари - градители. Машката носија, со природно бела боја на волната, како препознатлив културен елемент и средство за етноидентификација на Шопите, претставува невербален симбол и синоним на Шопите - планинци (Светиева, 2005, 13-14). Народното градителство и обредните форми, исто така, се карактеристични етнографски одлики на материјалната и на нематеријалната култура на Шопите. Но и денес, кога се работи за етнонимот Шоп и за етногенезата на Шопите, постојат повеќе претпоставки и тези, така што во науката овие прашања не се се разјаснети докрај.

\section{Селскостопански објекти во Кривопаланечко}

Селскостопанските објекти, кои се наоѓаат во рамките на селскиот двор или надвор од дворот, имаат значајна улога за животот и во стопанисувањето на населението во етничкиот предел Кривопаланечко. Тие се користат за: чување храна за семејството, храна за добитокот, чување на добитокот, чување на селскостопанските алатки и орудија и за други намени. Конструктивните елементи, кои се применети во изградбата на стопанските објекти, најчесто се од природен материјал: камен, дрво, земја, слама, трска. Објектите биле градени со примитивни алати: секира, тесла, пила, сврдел, чекан, мистрија и сл. Каменот се користи за изградба на приземјето на објектите, а дрвото се користи во изведба на бондрук-конструкцијата, која најчесто се применува за изградба на зидови над приземјето. Таа претставува скелетна дрвена конструкција, која се состои од хоризонтални и вертикални греди (14/14 или 16/16 см), прицврстени со косници. Од внатрешната и од надворешната страна на дрвениот скелет се заковани делкани штици, на кои се нанесува малтер и кал од двете страни. Просторот меѓу штиците останува празен, се пополнува со кал или со непечени тули - плитар. Многу често, бондрукот на зидовите од селскостопанските објекти во Кривопаланечко е пополнет со плет од дрвени прачки и непечени тули - плитар, измачкани со кал или на бондрукот, од надворешната страна, се заковани делкани штици. Покривната конструкција на стопанските објекти се изведува од дрвена граѓa (греди, штици и летви) и таа е на две или четири води. Како покрив се употребува 'ржаница, камени плочи - шкрилци, ќерамиди, лим и во поново време - салонитки.

Амбарот претставува еден од најзначајните селскостопански објекти во Кривопаланечко.

Се користи за чување жито и брашно. Тој може да биде составен дел на селската куќa и поставен на чардакот или во тремот на куќата, или како самостоен објект во селскостопанскиот двор. Амбарот, кој е составен дел на селската куќа, има квадарна форма, изведен е од дрво (греди, талпи и штици), а внатрешноста е преградена на неколку делови - пресеки за чување различни 
видови житни зрна. Тој е издигнат на камења - над земјата, заради заштита од влага. Самостојниот амбар се состои од две нивоа, приземје - подрум (земник) и кат - амбар. Подрумот - земникот е изграден од камења поврзани со кал и тој е најчесто вкопан со еден дел в земја. Во земникот се чува: зимница, качиња со урда и сирење, буриња со вино и ракија или тој може да се користи како кочина за свињи. Катот - амбарот се состои од душеме направено од греди и штици и зидови изведени со камења поврзани со кал, или од талпи и штици, непечени тули - тугли, или од плет измачкан со кал и слама. Во амбарот се направени дрвени преградни делови - пресеки за чување различни видови житни зрна. Покривот на самостојниот амбар е дрвена конструкција на две или четири води, покриен со: 'ржаница, камени плочи, ќерамиди или салонитки. Амбарот може да има трем и чардак, кои се користат: за сушење пиперки, за садови за зимница, за остава и сл. (фот. бр. 1).

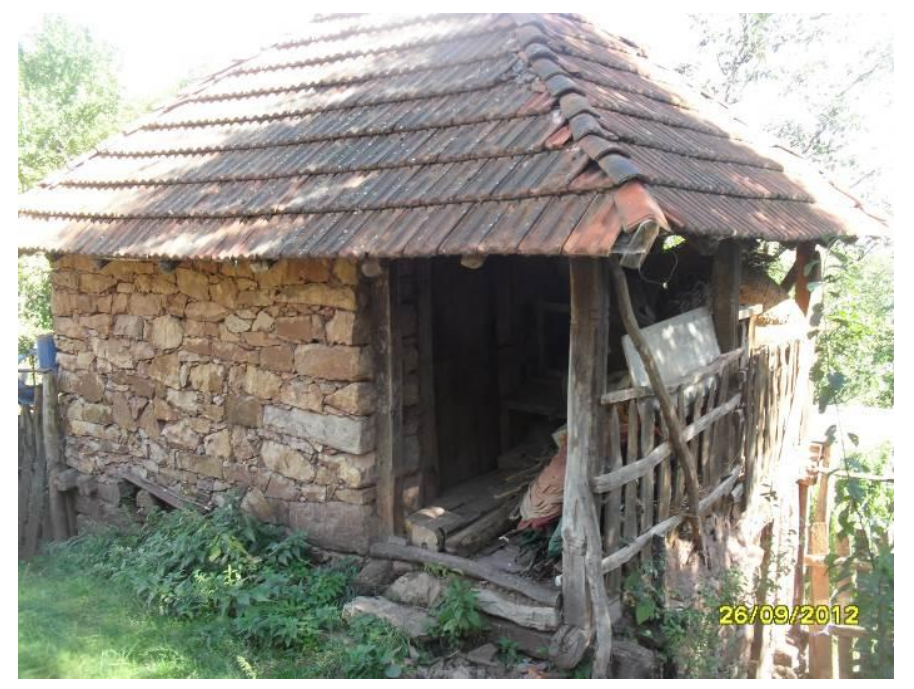

Фотографија бр. 1. Предна и бочна страна на амбар со подрум - земник, с. Голема Црцорија

Плевната - племњата се користи за чување добиточна храна (слама и сено). Таа обично е лоцирана во близина на шталата. Плевната има правоаголна основа со приземје или со приземје и кат. Приземните плевни најчесто се изградени од греди и штици и дрвена кровна конструкција на две или четири води, покриена со: 'ржаница, ќерамиди и салонитки. Плевните со приземје и кат најчесто се изградени од камења (приземјето) (фот. бр. 2), а катот е изграден од камења, греди и штици (фот. бр. 3), непечени тули или од плет измачкан со кал и слама и дрвена кровна конструкција на две или четири води, покриена со: 'ржаница, ќерамиди или салонитки. Во приземниот дел jap се чува добиток (говеда и овци, одвоени со дрвена преграда), а на катот се чува слама и сено. Плевните можат да бидат лоцирани и надвор од стопанскиот двор, бидејќи селата во етничкиот предел Кривопаланечко се од разбиен тип. 


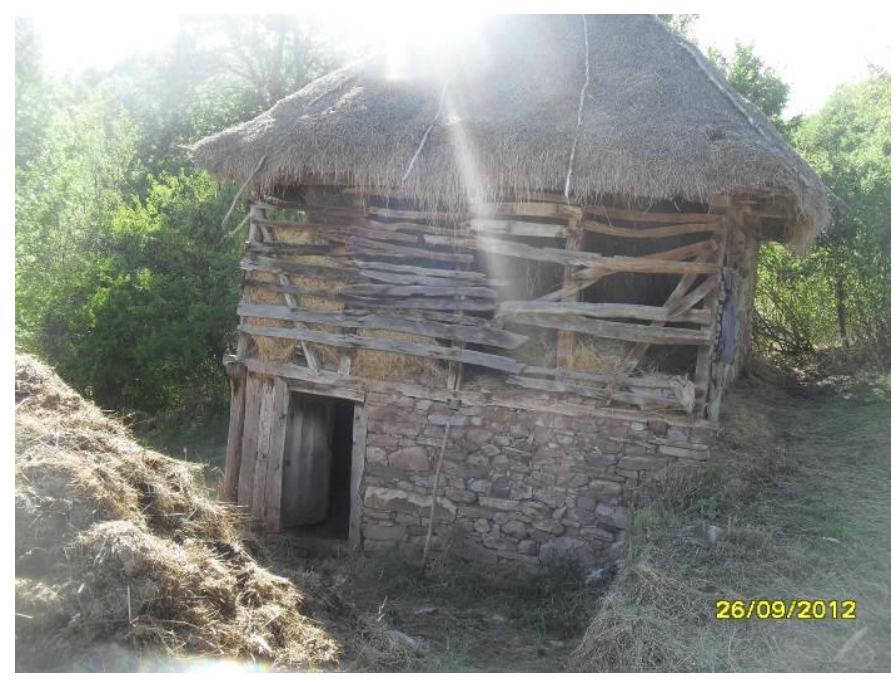

Фотографија бр. 2. Бочна страна на племна - племњ $а$, с. Голема Црцорија

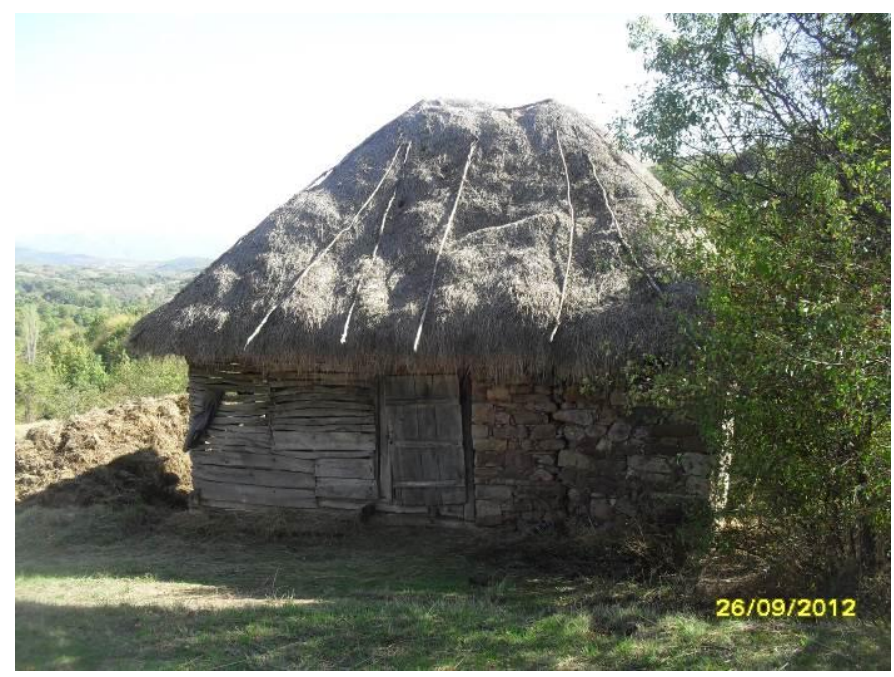

Фотографија бр. 3. Предна страна на племна - племњ $а$, село Голема Црцорија

Шталата - говедарникот се користи за чување крупен добиток (говеда). Таа обично е лоцирана во близина на плевната, заради полесен дотур на сточна храна. Шталата е приземен селскостопански објект со правоаголна основа, изградена најчесто од камен ( мидовите) и дрвена кровна конструкција на две води покриена со: 'ржаница, ќерамиди или салонитки (фот. бр. 4). Внатре во шталата, покрај ьидовите, се поставени дрвени корита - јасли за ставање сточна храна (сено и слама). 


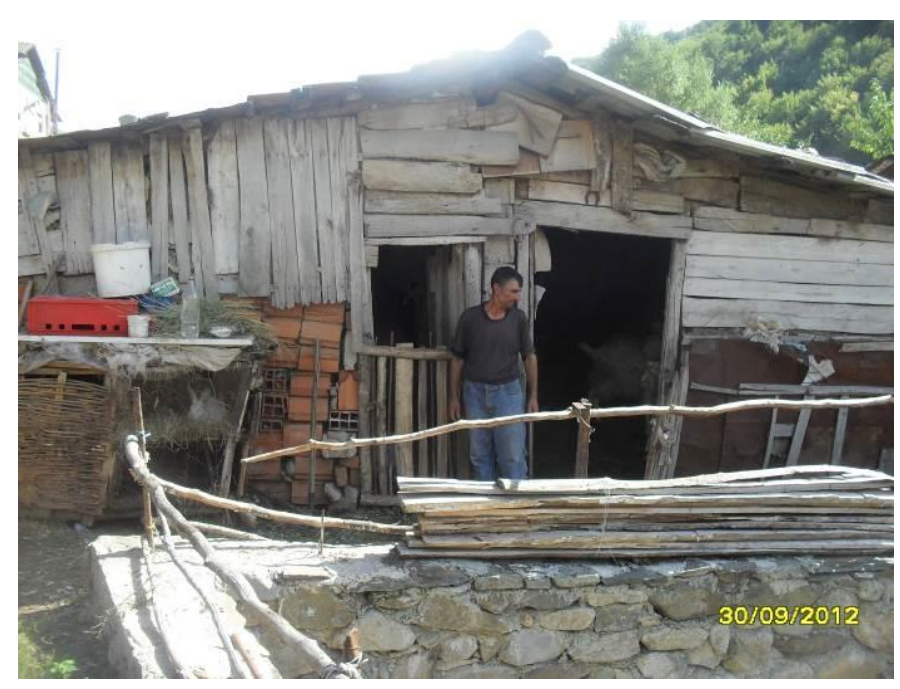

Фотографија бр. 4. Предна страна на штала, с. Жидилово

Кошот за чување пченкарни класја има правоаголна основа. Тој се состои од 4 греди, меѓусебно поврзани, на кои е поставено душемето од греди и талпи, 4 sидови направени од плет од дрвени прачки (заради овозможување на провев и сушење на пченката) и дрвена покривна конструкција на една или на две води, покриена со 'ржаница или со ќерамиди. Гредите се поставени на камења, заради заштита од влага. За уфрлање на класја во кошот постои отвор во горниот дел, а за вадење класја од кошот постои отвор во долниот дел од кошот.

Во Кривопаланечко позастапени се кошевите со приземје и кат. Приземниот дел на кошот е изграден од камења поврзани со кал. Се користи како кочина за свињи или како остава. Катот на кошот се состои од душеме направено од греди и талпи, зидови направени од плет од прачки (заради овозможување на провев и сушење на пченката) и дрвена кровна конструкција на две или четири води, покриена со 'ржаница или со ќерамиди. Кошот на катот има трем и чардак, кои се користат за складирање вреќи со пченкарни класја.

Трлото за чување овци е лоцирано надвор од стопанскиот двор (кога се работи за големо стадо овци) или во стопанскиот двор (кога се работи за мало стадо овци). Трлото е заградено со ограда од плет наречена аргач. На влезот од аргачот се поставува ограда од плет - страга, каде што се задржуваат овците за молзење. Трлото има покриен дел - поја за лежење на овците преку зима, направен од камен или плет од прачки и дрвена покривна конструкција на една вода покриена со 'ржаница. До задниот sид на појата се поставени јасли направени од плет, во кои се става сено (храна за овците). Јаслите се високи околу 50 см за да не можат да влегуваат во нив овците и за да не можат да го газат сеното. Во отворениот дел на трлото е поставено долго издлабено дрво - корито во кое се: става трици, јачмен или пченка (за зобење на овците) 
и раниште направено од штици и плет од прачки, во кое се става сено. Раништето е високо околу 70 см. Најчесто, овци се чуваат во приземниот дел на плевната, наречен јар, во кој, до мидовите, има дрвени корита - јасли, во кои се става храна за овците.

Кочината за чување свињи е сместена во стопанскиот двор. Кочината е изградена од камења поврзани со кал, од плет или штици, со дрвена покривна конструкција на една вода, покриена со слама или ќерамиди. Подот на кочината е поплочен со камења. Вратата на кочината е направена од штици, а дрвеното издлабено корито, во кое се става храна за свињите, се нарекува копанка (фот. бр. 5).

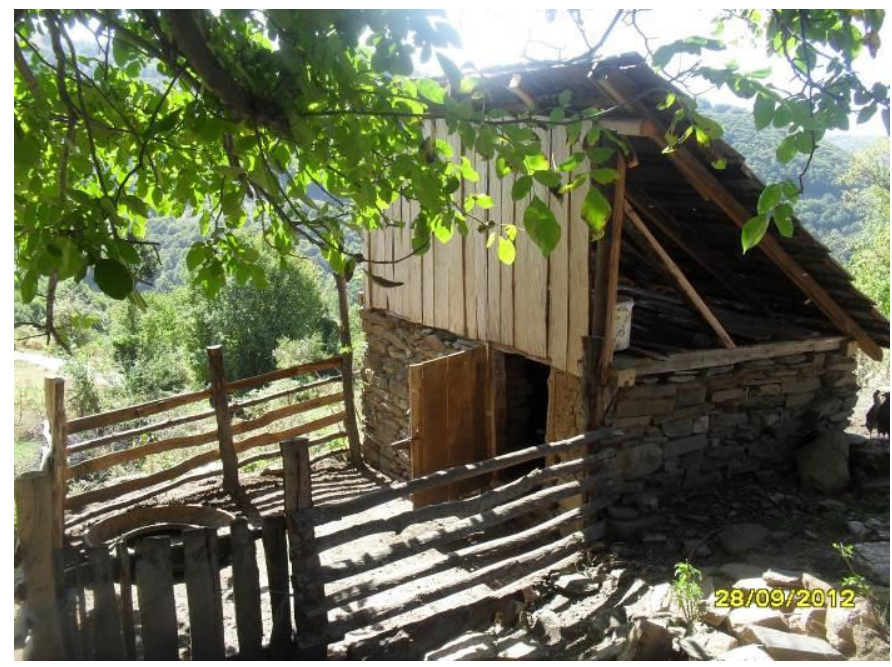

Фотографија бр. 5. Предна и бочна страна на кочина за свињи, с. Нерав

Кокошарникот за чување кокошки е сместен во стопанскиот двор, во близина на куќата. Кокошарникот е изграден од камења поврзани со кал, од плет или штици, со дрвена покривна конструкција на една вода, покриена со слама, ќерамиди или салонитки. Вратата на кокошарникот е направена од штици и таа е ниска и мала (фот. бр. 6). 


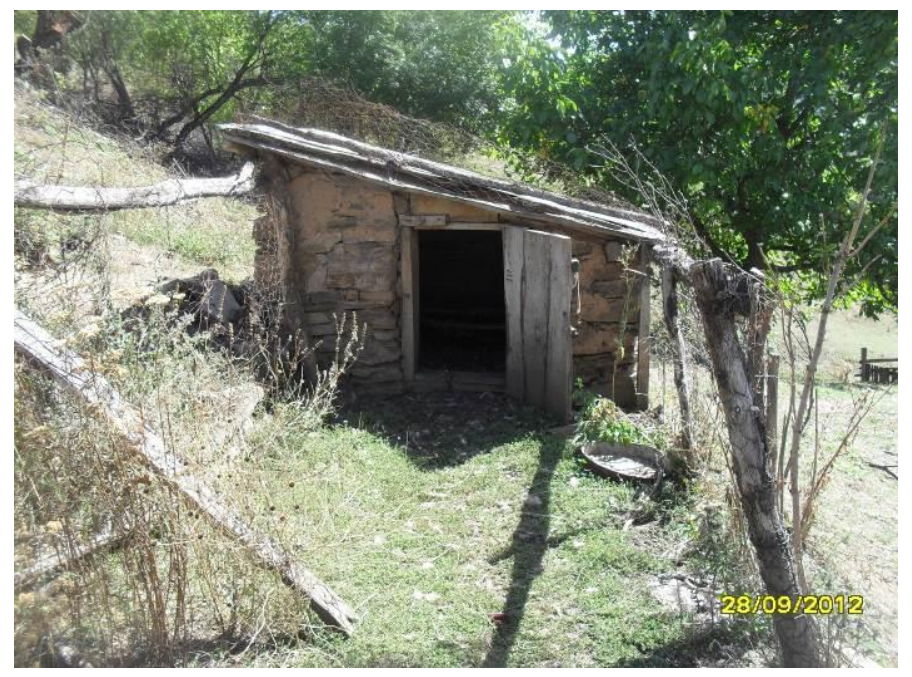

Фотографија бр. 6. Кокошарник за чување кокошки, с. Нерав

Казаница, казарница е објект сместен во стопанскиот двор, во кој има sидан казан за варење ракија. Казаницата има правоаголна основа. Аидовите се изведени од камења поврзани со кал. При зидањето се оставаат 3 отвори: отвор за светло, отвор за исфрлање на комињето од казанот и отвор за врата. Покривот на казаницата е дрвена конструкција на две води, покриен со: 'ржаница, камени плочи, ќерамиди или салонитки. До задниот sид на казаницата е соsидан казанот за варење ракија. Огништето - печката на казанот е соsидано од камени плочи и кал од земја - иловица. Тоа е со димензи: 100x80x70 см (должина х ширина х висина). Огништето има 2 отвори, долен правоаголен отвор за ложење дрва и горен кружен отвор во кој е поставен горниот свиткан обод на бакарниот котел - казан. На ободот од казанот е поставен земјен ќуп (капак на казанот) со долниот кружен отвор, а на горниот обод од ќупот (горниот кружен отвор) е поставено земјено грне со долниот кружен отвор. Долните делови од двете лули на грнето се поставени во отворите на двете метални лули од металното буре - крбла, наполнето со вода. Металните лули се поставени во средината на крблата, од горе до долу. Крблата може да биде соsидана и од камен. Споевите на казанот, ќупот, грнето и лулите се лепат со тесто, за да не влегува воздух во казанот. Казаницата може да биде сместена во подрумот - земникот на селската куќа (фот. бр. 7), во тремот од куќата или до зидот од куќата (фот. бр. 8). Кога казаницата е сместена до зидот од куќата, таа е покриена со надстрешница со ќерамиди. Со ложење дрва во огништето, алкохолот во вид на пареа излегува од комињето и поминува низ ќпот, грнето и лулите, во кои, под влијание на студената вода во крблата, настанува процес на кондензација на алкохолот и негово претварање во течност. Ракијата излегува низ долните тесни отвори од металните лули. 


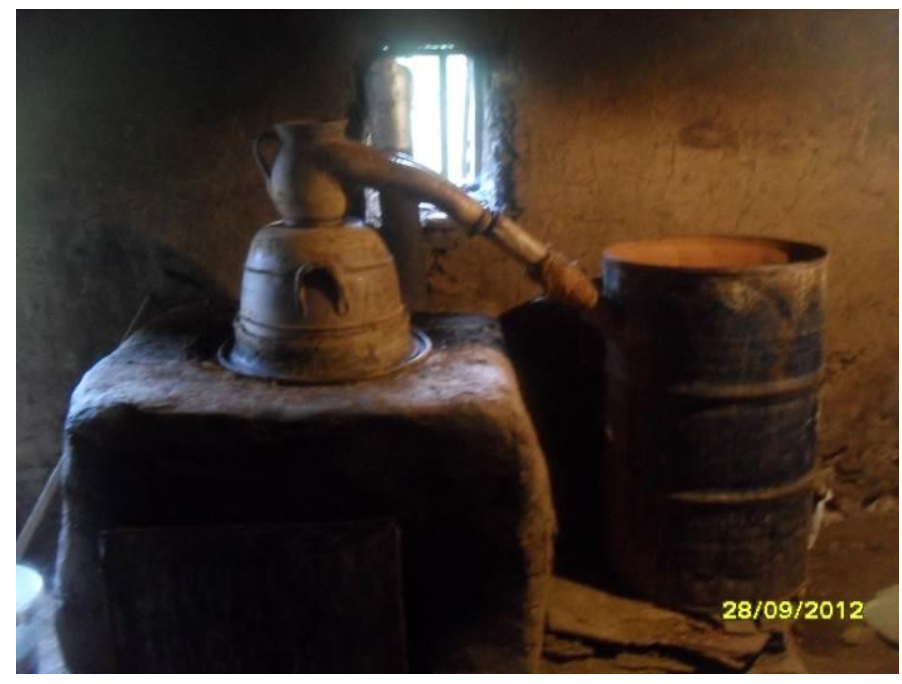

Фотографија бр. 7. Фидан казан за варење ракија, сместен во земник од куќа, с. Огут

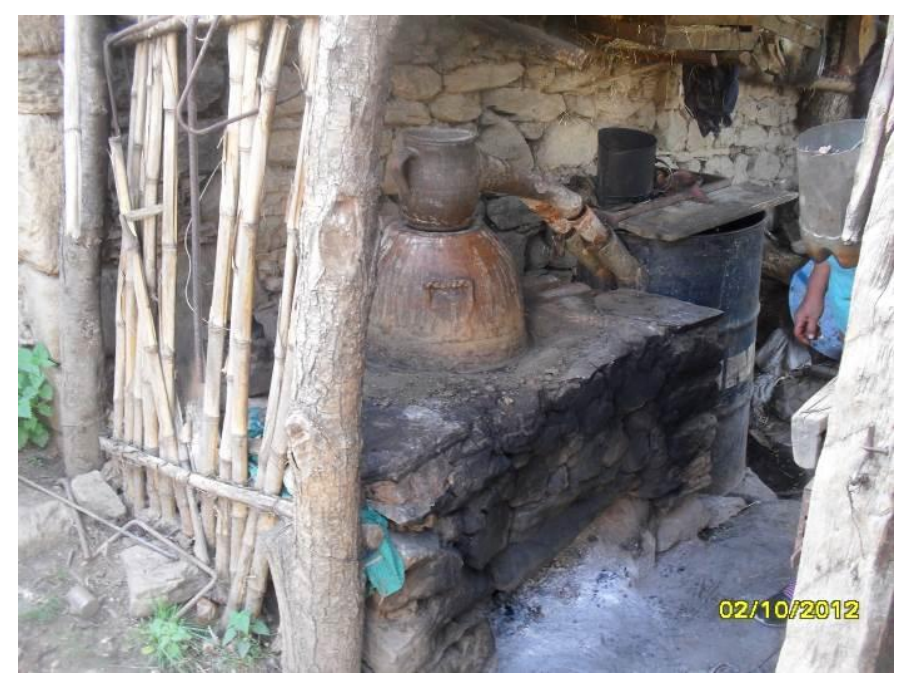

Фотографија бр. 8. Казаница за варење ракија, поставена до sид од куќа, с. Мождивњак

Фурната за печење леб е сместена до мидот од куќата (фот. бр. 9), во тремот од куќата или во стопанскиот двор (фот. бр. 10). Фурната е подsидана со камења. Таа е изградена од камења, камени плочи, кал и печени полни тули. На внатрешната страна од sидовите - ложиштето, каде што се пече лебот и сводот, е соsидан внатрешен зид од печени полни тули. Долниот дел на фурната - подот е соsидан од рамни камени плочи. На задниот дел од подот има отвор за паѓање на пепел и жар. Сводот, исто така, има отвор - оџак за излегување на чад. На предната страна од фурната има голем отвор - врата на 
ложиштето, кој се затвора однадвор со метален капак со рачка. Покривот на фурната е дрвена конструкција на една вода, покриена со: ќерамиди, камени плочи или лим. Печењето леб се прави на следниот начин: во ложиштето се ставаат и се ложат дрва. Штом ќ се формира жар, од ложиштето се вади жарот и пепелот и во него се става со дрвена лопатка измесениот леб. Отворот на ложиштето се затвора со металниот капак, а отворот на оџакот се затвора со влажна крпа или со метален капак. Лебот во фурната се пече околу 30 минути.

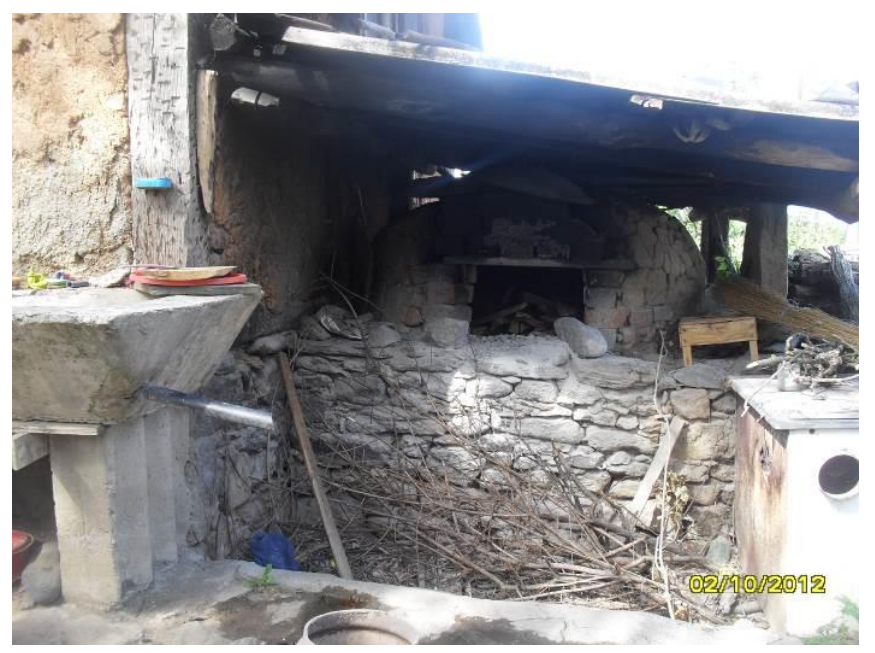

Фотографија бр. 9. Фурна за печење леб која има форма на купола. Фурната е поставена до sид од куќата и е покриена со натстрешница од салонитки, с. Мождивњак.

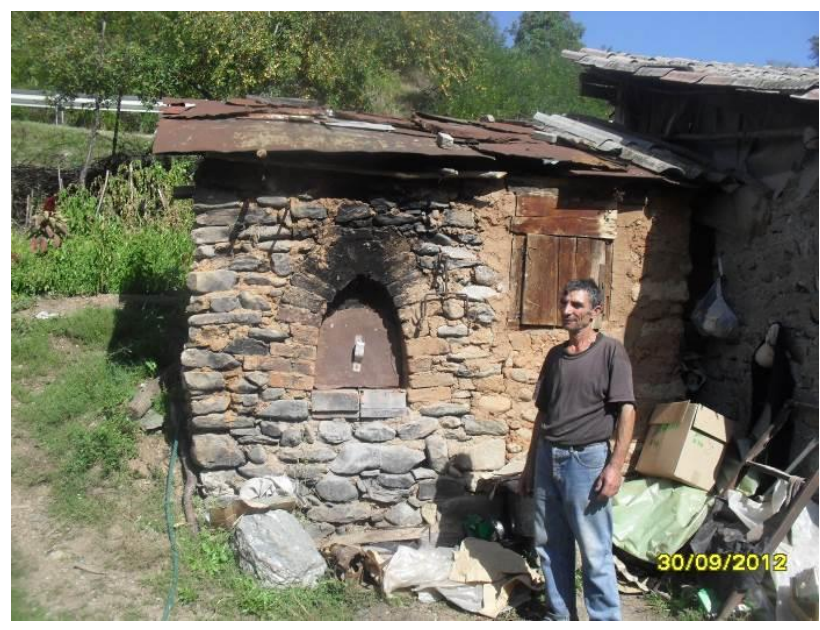

Фотографија бр. 10. Предна страна на фурна за печење леб и сушара за месо, с. Жидилово 
Сушарата за месо и фурната обично се сместени во еден селскостопански објект во стопанскиот двор (фот. бр. 10) или во тремот од куќата. Таа е изградена од камења измачкани со кал. Сушарата, во долниот дел, има ложиште за ложење дрва, зад него - лим со песок за цедење на месото, а на сводот има отвор - оџак за излегување на чадот. На предната страна од сушарата има квадратен отвор - врата, кој се затвора со дрвено вратниче. Во сушарата, непосредно до предниот и до задниот sид се поставени две паралелни дрвени прачки, на кои се заковани 5 до 6 попречни дрвени прачки со метални ченгелчиња. Сушењето месо се прави на следниот начин: кога ке се извади месото со солило од каче, тоа се се закачува на ченгелчињата во сушарата и се цеди 24 часа. Потоа се ложи средно силен огин 8 часа, па потоа, навечер, се прекинува ложењето дрва. Следното утро се ложи 8 часа, а потоа месото „се пуши“ на жар. Постапката се повторува 5 дена и 4 ноќи. Кога не се ложат дрва, а месото „се пуши“ на жар, отворот на оџакот се затвора со решетка.

Пчеларникот - улиште за чување пчели е сместен во стопанскиот двор или надвор од него. Пчеларникот е составен од кошници - трмки направени од плет од прачки и покриени со слама 'ржаница или од дрвени сандаци за пчели (фот. бр. 11).

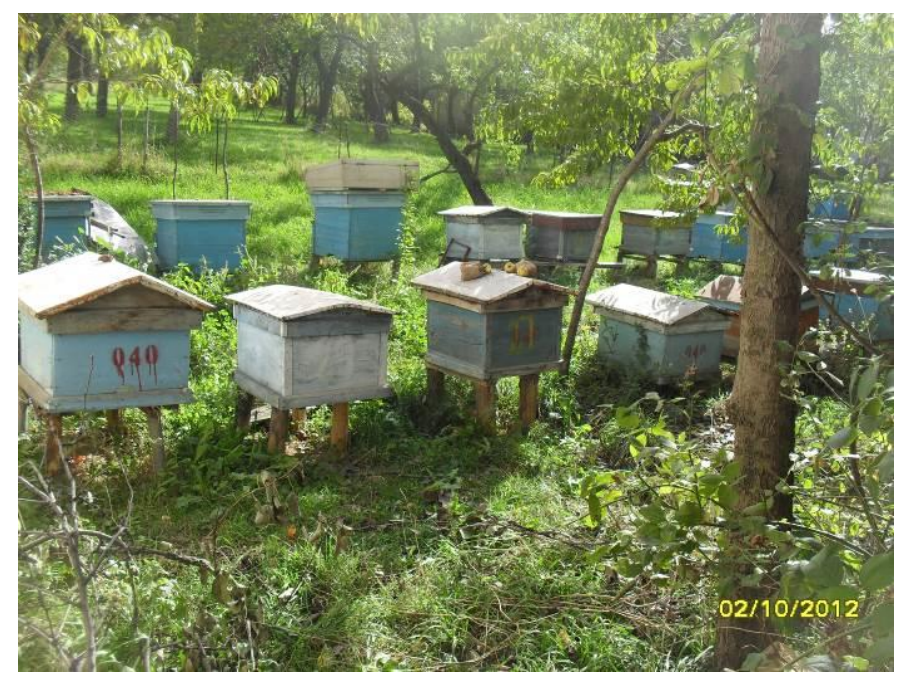

Фотографија бр. 11. Улиште со сандаци за пчели, кое се наоѓа во овоштарник, с. Конопница

Бунар за снабдување со вода. Бунарите биле градени на одделни места во селата и тие имале општоселски карактер. Меѓутоа, има бунари и во селскостопанскиот двор, во близина на куќата. Има повеќе типови бунари: бунар со вител, со чекрк и бунар со герам. Најраспространети се бунарите со вител. Страните на подземниот дел од бунарот т. е. дупката што има кружна основа, се соsидани/е соsидана со камен без малтер. Оградата околу дупката е 
направена од монолитен камен или од дрво. Бунарот со вител се состои од ограда, разбој и покривна конструкција на две води, покриена со ќерамиди или лим. Оградата, разбојот и покривната конструкција се направени од гредички и штици (фот. бр. 12). На разбојот е поставен дрвен вител со метална рачка на крајот, а на средината на вителот е намотан синџир. На долниот крај од синџирот е закачена метална кофа. Со вртење на рачката со вителот, синџирот се намотува и се одмотува на вителот, при што кофата со вода се вади од бунарот и обратно.

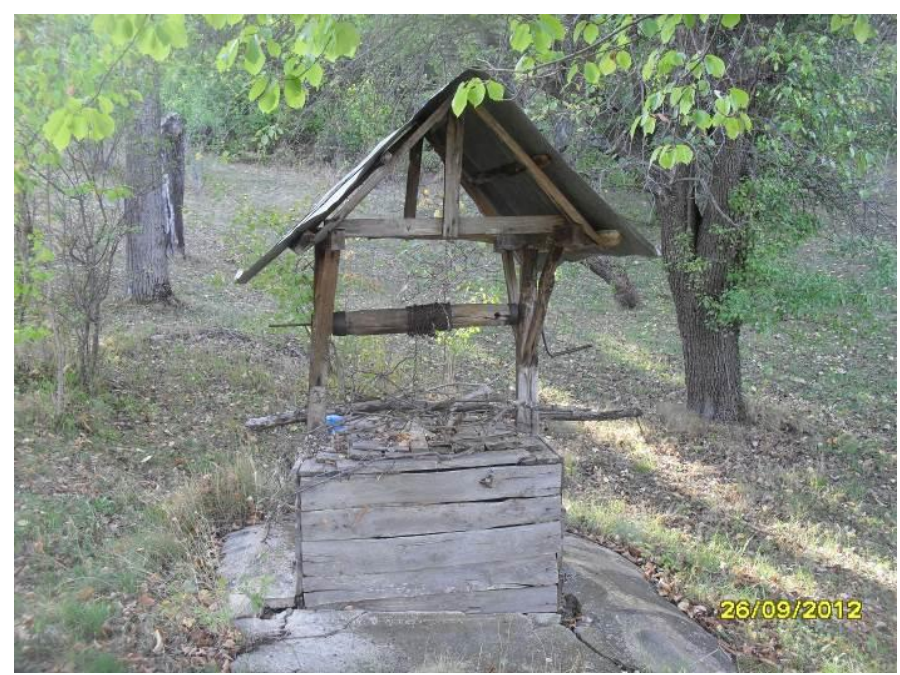

Фотографија бр. 12. Бунар со вител, с. Голема Црцорија

Во селата и надвор од селата во употреба се и други селскостопански објекти од исклучително заначење за селаните, како што се: водениците, валавиците и други објекти.

Водениците што се користат за мелење жито се граделе покрај реките и потоците. Тие биле изградени од: камења, греди, штици и плет измачкан со кал од земја иловица и дрвена покривна конструкција на две води, покриена со 'ржаница или со ќерамиди (фот. бр. 13). Работниот дел на воденицата, сместен во приземјето на објектот воденица (фот. бр. 14), се состои од следните делови: дрвено скеле на кое е прицврстен буков кош со горен правоаголен отвор (80х60 см) и долен квадратен отвор (10х10 см), букова коритеста кутлииа поставена под долниот отвор на кошот, багремова штичка кречетало, поврзана со кутлицата, горен метален дел од вертикално багремово вретено на чиј крај е поставен метален сен, на кој е вглавена хоризонтална метална плочка - прплица, на која пак, е насаден: горниот воденички камен преку жлебот на неговата долна страна, долен воденички камен со кружен отвор во средина во кој е поставен врбов прстен (гужлеи) и буково корито - мучник. Долниот дрвен дел на вретеното поминува низ подот - душемето и завршува во вкопаниот погонски дел на воденицата. Во 
долниот дел на вретеното е вглавено хоризонтално метално тркало - коло со перки, а под колото, на крајниот долен дел од вретеното е поставен метален сењ. Сењот го држи колото и на него се врти колото. Долниот шилест дел на сењот е поставен во метална плочка, закована на средина од дрвена хоризонтална греда - баба. Бабата со едниот краен чаталест дел е прицврстена на хоризонтална созидана греда - сантрач, а со другиот краен дел е прицврстена на долниот дел од вертикална багремова греда - cmapeu, чиј горен дел поминува низ душемето од воденицата. Со cmapeuоm се подига и се спушта горниот воденички камен, заедно со вретеното и колото и на тој начин се регулира мелењето на житото (се добива покрупно и поситно брашно). Со пуштање на вода од јазот - вада во буковата коруба, бликот вода удира на перките од колото и го задвижува. Со колото се задвижуваат вретеното и горниот воденички камен. При вртење на горниот камен, кречеталото се задвижува и ја растресува кутлицата во која постепено паѓаат житни зрна од кошот, а од неа зрната паѓаат во отворот на горниот и на долниот камен, при што се врши нивно мелење. Брашното од измелените житни зрна се собира во коритото - мучник, поставено пред воденичките камења.

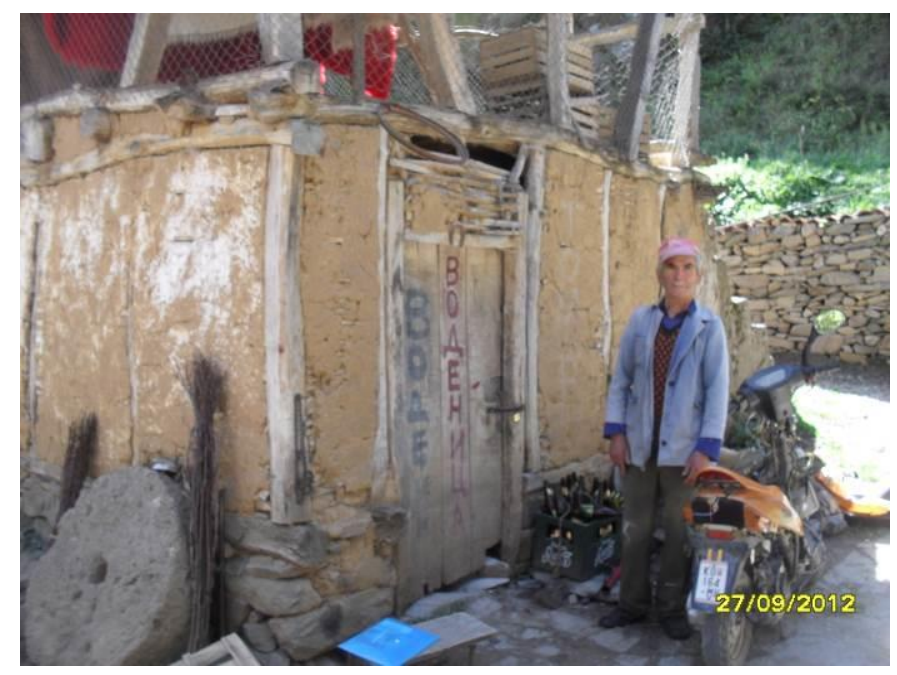

Фотографија бр. 13. Предна и бочна страна на воденица со отворена катна дрвена конструкција и покрив на две води, покриен со поцинкован лим, с. Станци 


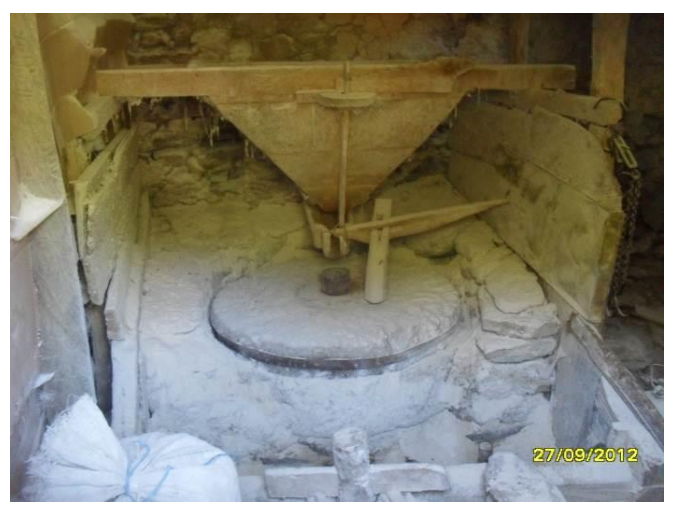

Фотографија бр. 14. Работен дел на воденица, с. Станци

Валавиците, кои се користат за валање јамболлии, килими, шајак, како и за перење на волнени и козинави ткаеници, се граделе покрај реките и потоците. Постојат два типа валавици, водена валавица - вир (кош) за валање јамболлии и килими (фот. бр. 15) и сува валавица за валање шајак. Водената валавица е изградена на отворено, а сувата валавица е сместена во објект сличен на воденица. Кошот претставува голем сад во форма на пресечен конус составен од 22 букови штици долги $220 \mathrm{~cm}$, вкопани околу $180 \mathrm{~cm} \mathrm{во}$ земја. Ширината на штиците на долниот крај изнесува 5 см, а на горниот крај (над земја) - 10 см. Пречник на горниот кружен отвор од кошот изнесува 150 см, а на долниот кружен отвор - 50 см. Пред да се постават штиците во дупката, sидовите на ископаната конусна дупка се подзидуваат со камења, при што на средина од sидовите се зазидуваат повеќе багремови трупчиња во круг, на кои се заковуваат штиците од кошот. Горниот и долниот дел на штиците се опфатени со брезови обрачи. Долниот крај на штиците се поставува меѓу кружна камена плоча и долниот дел од зидот. Штом ќе се пушти вода од јазот - вада во буковата коруба, која со долниот дел е поставена на горниот раб од штиците, бликот вода создава кружно движење на водата во кошот, при што ткаениците се вртат и се валаат (фот. бр. 16). Водата излегува меѓу штиците во горниот дел. Сочувани валавици, кои се во функција, има во селата Станци и Дурачка Река. 


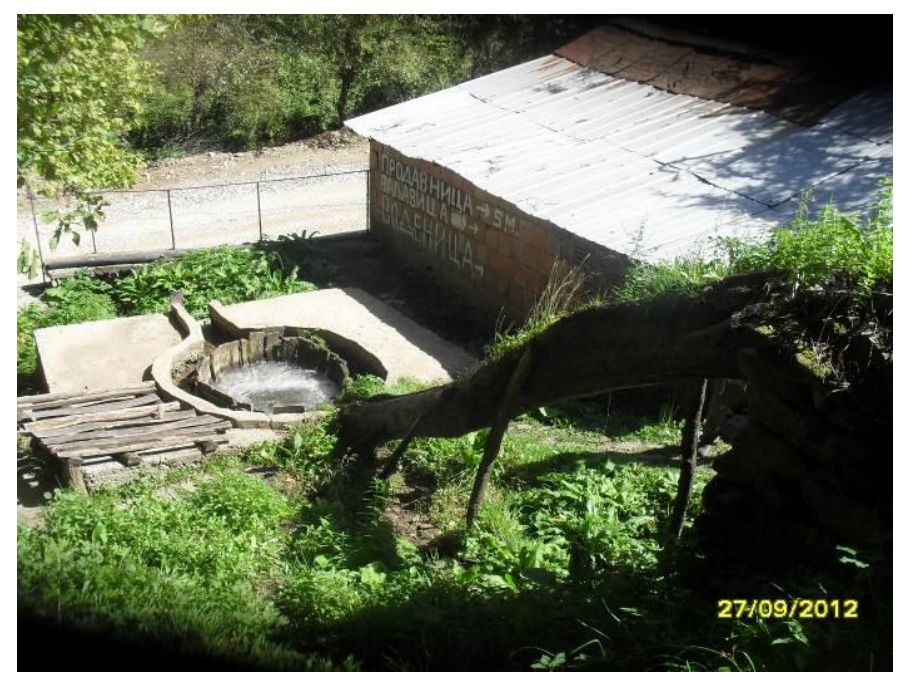

Фотографија бр. 15. Водена валавица - вир (кош) со букова коруба, за валање јамболлии и килими, с. Станци

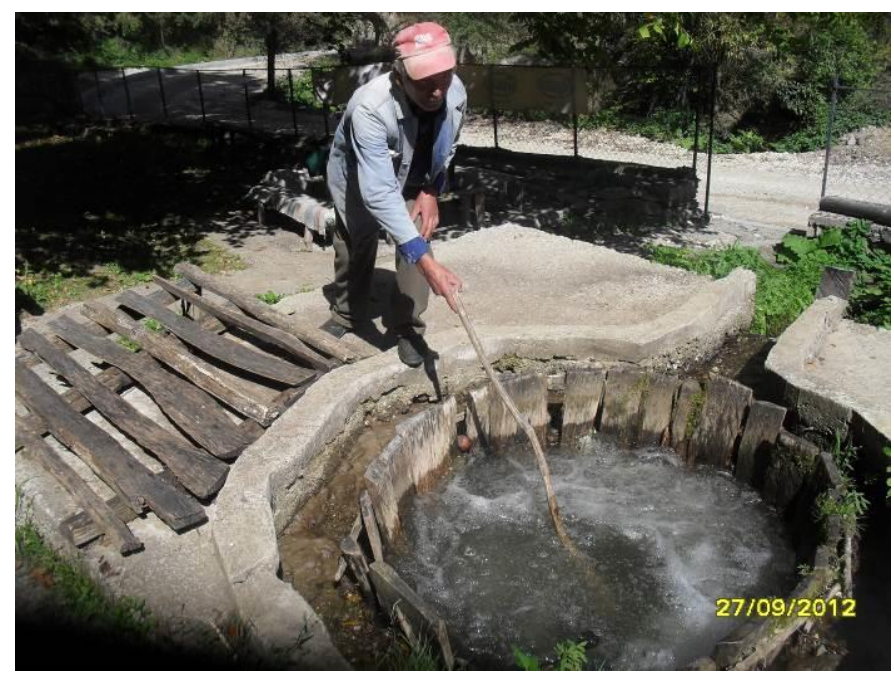

Фотографија бр. 16. Вадење на извалана ткаеница од кошот и нејзино поставување на скеле за цедење, с. Станци

Во минатото, освен овие карактеристични селскостопански објекти во Кривопаланечко, постоеле и селскостопански објекти, кои биле надвор од селата, како сточарски колиби и бачила во рамките на привремените сточарски населби, полски колиби, лозарски колиби и сл. (Томовски, 2006, 9094).

Бачила во состав на трлата имало на Осоговските Планини. Бачило претставува стопански објект изграден од камења и кал или од плет од прачки и дрвена кровна конструкција на една вода покриена со 'ржаница. Тоа има две 
простории и две врати поставени на двете спротивни страни. Во едната просторија била сместена покуќнината на сточарите (кревети, столчиња, прибор за јадење и сл.), а во другата просторија биле сместени садовите и приборот за преработка на млеко во млечни производи (каца за потсирување на млеко, качиња за сирење и урда, калапи за кашкавал, работна маса и сл.).

Народното градителство на шопската етничка заедница се формирало во зависност од општествено-економските услови и од локалните традиционални сфаќања за формата на живеалиштата и на селскостопанските објекти. Градителството најинтензивно се развивало во 19 и на почетокот на 20 век, кога се востановиле одредени традиционални форми на живеалиштата и на селскостопанските објекти. Меѓутоа, миграциите и општествено-економските промени, кои се случиле во втората половина на 20 век, имале силно влијание врз шопската етничка заедница, особено во традиционалното градителско наследство. Но и покрај тоа, Шопите успеале да сочуваат дел од етничките карактеристики во доменот на материјалната и на нематеријалната култура.

Забелешка: Етнолошките податоци во оваа статија се од моето теренско истражување во етничкиот предел Кривопаланечко, реализирано во период од 24.09.2012 до 04.10.2012 година. Теренското истражување во етничкиот предел Кривопаланечко, кој е во состав на Шопската етничка област, беше прва фаза од проектот: Етнолошко истражување на Шопската етничка област во Македонија. За време на истражувањето ги посетив населените места: Крива Паланка, Луке, Подржи Коњ, Крстов Дол, Голема Црцорија, Мала Црцорија, Станци, Дурачка Река, Нерав, Огут, Узем, Жидилово, Градец, Лозаново, Мождивњак и Конопница.

\section{Извори:}

Етнолошки атлас, Филозофски факултет Загреб, Здружение на етнолозите на Македонија Скопје, Скопје 7 мај 1983

Сопствени теренски истражувања реализирани во Кривопаланечко во периодот од 24.09. до 04.10.2012 година.

\section{ЛИТЕРАТУРА}

Светиева, А. (2005). Шопи. Етнолог 11. Македонско етнолошко друштво. Скопје.

Томовски, К. (2006). Населби и народна архитектура. Етнологија на Македонците. Скопје: МАНУ.

\section{Информатори:}

Георгиевски Василко, роден 1950 г. во с. Мождивњак. Тој ги даде податоците во врска со конструктивните карактеристики и функционалноста на фурната и казаницата во с. Мождивњак. 
Димитровски Раде, роден 1966 г. во маало Петковци - Големи Гар, с. Луке. Тој ги даде податоците во врска со конструктивните карактеристики и функционалноста на плевните во маало Петковци - Големи Гар, с. Луке.

Јакимовски Владо, роден 1943 г. во с. Дурачка Река, доселен во с. Станци во 1963 г. Тој ги даде податоците во врска со конструктивните карактеристики на воденицата и на водената валавица - вир (кош), како и за начинот на мелење жито во воденица и за начинот на валање ткаеници во кош во с. Станци.

Митевски Велин, роден 1928 г. во с. Мождивњак. Тој ги даде податоците во врска со конструктивните карактеристики и функционалноста на амбарот, фурната и казаницата во с. Мождивњак.

Петровски Борис, роден 1956 г. во маало Парапунци, с. Нерав. Тој ги даде податоците во врска со конструктивните карактеристики и функционалноста на плевните, кокошарникот и кочината во маало Парапунци, с. Нерав.

Станковски Љубен, роден 1950 г. во с. Огут. Тој ги даде податоците во врска со конструктивните карактеристики и функционалноста на плевната и казаницата, сместена во земникот на куќата во с. Огут.

Цветановски Радослав, роден 1952 г. во с. Жидилово. Тој ги даде податоците во врска со конструктивните карактеристики и функционалноста на фурната, сушарата и шталата во с. Жидилово.

Bore Nedelkovski

\section{VERNACULAR HUSBANDRY STRUCTURES IN THE ETHNIC AREA OF KRIVA PALANKA}

Summary

The article presents the anthropological-geographic data on Makedonski Shopluk, that is, the ethnic area of Kriva Palanka and its settlements. It also elaborates the symbolic meaning of the ethnonym/exonym Shop with all its specific features.

A special consideration in the article has been given to vernacular husbandry structures in the Kriva Palanka area, which were constructed of natural building materials: wood, stone, earth, straw and reed. Wood was used for building bondruck structure, which was most frequently applied in construction of walls above the ground-floor. In addition to the structural characteristics, the article presents the functional features of the following vernacular husbandry structures: granary for keeping cereals and flour, barn for storing hay and straw, cattle shelter, kosh for keeping corn ears, sheepfold, pigsty, chicken coop, brandy-making cauldron, bread-baking furnace, meat-drying structure, apiary for keeping bees, water well, water-mill for grinding grains and rolling-mill for rolling woollen fabrics. 